\title{
RESIDENTIAL MOBILITY ACROSS LOCAL AREAS IN THE UNITED STATES AND THE GEOGRAPHIC DISTRIBUTION OF THE HEALTHY POPULATION
}

\author{
by
}

\author{
Arline T. Geronimus ${ }^{1}$ \\ University of Michigan
}

\author{
John Bound ${ }^{2}$ \\ University of Michigan
}

\author{
Annie $\mathbf{R o}^{3}$ \\ UC Irvine
}

CES 14-14

February, 2014

The research program of the Center for Economic Studies (CES) produces a wide range of economic analyses to improve the statistical programs of the U.S. Census Bureau. Many of these analyses take the form of CES research papers. The papers have not undergone the review accorded Census Bureau publications and no endorsement should be inferred. Any opinions and conclusions expressed herein are those of the author(s) and do not necessarily represent the views of the U.S. Census Bureau. All results have been reviewed to ensure that no confidential information is disclosed. Republication in whole or part must be cleared with the authors.

To obtain information about the series, see www.census.gov/ces or contact Fariha Kamal, Editor, Discussion Papers, U.S. Census Bureau, Center for Economic Studies 2K132B, 4600 Silver Hill Road, Washington, DC 20233, CES.Papers.List@census.gov. 


\begin{abstract}
Determining whether population dynamics provide competing explanations to place effects for observed geographic patterns of population health is critical for understanding health inequality. We focus on the working-age population where health disparities are greatest and analyze detailed data on residential mobility collected for the first time in the 2000 US census. Residential mobility over a 5-year period is frequent and selective, with some variation by race and gender. Even so, we find little evidence that mobility biases cross-sectional snapshots of local population health. Areas undergoing large or rapid population growth or decline may be exceptions. Overall, place of residence is an important health indicator; yet, the frequency of residential mobility raises questions of interpretation from etiological or policy perspectives, complicating simple understandings that residential exposures alone explain the association between place and health. Psychosocial stressors related to contingencies of social identity associated with being black, urban, or poor in the U.S. may also have adverse health impacts that track with structural location even with movement across residential areas.
\end{abstract}

Keyword: place and health, residential mobility, race and health, SES, urban, rural

\footnotetext{
${ }^{1}$ Professor, Department of Health Behavior and Health Education, School of Public Health Associate Director \& Research Professor, Population Studies Center, Institute for Social Research, University of Michigan, 426 Thompson St., Ann Arbor, MI 48106-1248.

${ }^{2}$ George E. Johnson Collegiate Professor, Department of Economics; Fellow NBER Research Professor, Population Studies Center, Institute for Social Research, University of Michigan, 426 Thompson St, Ann Arbor, MI 481061248.

${ }^{3}$ Assistant Professor, Department of Population Health and Disease Prevention, Program in Public Health, UC Irvine, Anteater Instruction \& Research Bldg. (AIRB),Room 2036653 E. Peltason Road, Irvine, CA 92697-3957 Correspondence should be sent to Arline T. Geronimus: e-mail: arline@umich.edu phone: 734-763-2460 fax: 734763-1428
} 


\section{Introduction}

The possibility that the relationships between socioeconomic position or race/ethnicity and health are influenced by geographic and community conditions that structure and contextualize them has garnered great interest over the past decade or more (Davey Smith et al. 1998a; Hayward et al. 1997; Geronimus 2000; Diez Roux 2001; Nordstrom et al. 2004; Cozier et al. 2007;Freedman et al 2010). A resurgence of interest in the health impact of residence in highpoverty urban areas, in particular, has been notable among public health researchers (Galea and Vlahov 2005; Fitzpatrick and LaGory 2011), and also among sociologists who study residential areas characterized by urban decay, concentrated poverty, and racial segregation (Massey and Denton 1993; Wilson 1996). After reviewing the growing evidence on poverty, race, place, and health, Fitzpatrick and LaGory (2010) concluded: “until the public’s view of health encompasses a basic understanding that where we live affects how we live and die, the health status of certain segments of the population cannot improve.”

Geronimus et al. (1996,1999, 2001, 2011) analyzed differences in adult disability and mortality rates across a regionally diverse set of black and white, urban and rural, high-poverty and more affluent local populations, finding great variation in these rates across population types. Cause of death analyses from 1980 through 2000 documented a substantial and entrenched burden of chronic disease among working-age black men and women living in high-poverty areas (Geronimus, Bound, Colen 2011). Black adults in high-poverty urban areas faced extremely disadvantageous mortality schedules through middle and old age, not only in comparison to white or black national averages or to black residents of more affluent communities, but also compared to black residents of high-poverty rural communities. For example, age-standardized mortality ratios in 2000 for 18-64 year old black men or women in 
Southside Chicago and Delta Louisiana - two study populations in which $46 \%$ of families lived below the poverty line (and where high school and college graduation rates were substantially lower in the Louisiana compared to the Chicago population) - were greater than 3 times the national average in Chicago, yet only about 2 times the national average in Louisiana.

Standardized mortality rate differences between high-poverty urban and high-poverty rural areas suggest that place characteristics may have impacts on health above and beyond the effects of the sociodemographic characteristics of local populations. It may be reasonable to hypothesize that characteristics of urban areas undermine longevity or that aspects of rural areas confer protection. However, because most studies of place effects on health use cross-sectional data (Beard et al 2009; Diez-Roux 2007; Osypuk, et al. 2008; Shih et al 2011) ${ }^{1}$, this interpretation implicitly assumes static local populations. Yet, local populations are in fact dynamic, and health may be associated with population shifts over time. Thus, observed geographic patterns of health could also reflect the influence of health-related migration on the geographic distribution of the healthy population. These patterns underlie the health selective migration hypothesis, that differences in health profiles across distinct areas may arise, in part, because the residentially mobile may be more or less healthy than those who do not move. For example the $50 \%$ higher excess mortality in the poor black South Chicago population compared to the poor black Louisiana Delta population could be because of differences in place characteristics between the areas (including environmental exposures); it could be because of differences in populations between the two areas; or it could be because of a net out-migration of

\footnotetext{
${ }^{1}$ Some epidemiological studies follow sample members for two or more time points; however, samples are often selective, including healthy participants at baseline in order to note whether their disease status changes over the course of the study.
} 
the healthy from the Chicago or a net in-migration of the healthy into the Delta population (selective migration).

Gaining purchase on whether selective migration is an important competing explanation to place effects or to static compositional effects for health differences observed across local areas is critical for identifying the most promising future directions for research on racial/ethnic and socioeconomic inequalities in health and for policy to eliminate them. Considerable work has been done to explore the impact of selective migration on health among immigrants to and from the US, particularly in the context of the Hispanic Health Paradox (Palloni and Arias, 2004). Some UK studies have documented the important impact of selective migration on the health profiles of more and less distressed areas in that country (Brimblecombe et al. 1999, 2000; Norman et al, 2005). To our knowledge, we are the first researchers to address the health selective migration hypothesis in the context of residential mobility within the US.

The few investigators who have considered the relationship between local population health and residential mobility patterns within the U.S. have asked a different question, whether health influences the mobility decisions of those at or near retirement (Halliday and Kimitt 2008; Findley 1988; Longino et al. 1991, 2008; Speare et al. 1991). They do not focus on health disparities or the younger working-age population in which health disparities are greatest (Elo and Preston 1996; Geronimus 1992; Geronimus et al 2001, 2006, 2007) and do not consider the impacts of selective migration for the association between place and population health.

Health and Migration in the U.S.

There is reason to postulate that health and residential mobility may be associated. Several theoretical perspectives on residential mobility across neighborhoods in the U.S. highlight the importance to mobility decisions of the demographic and life-cycle characteristics 
of nuclear household heads - including age, sex, and marital status (South et al. 2005; Tolnay 2003). To the extent that the demographic and life-cycle characteristics influencing residential moves are associated with current or future health status, it is reasonable to hypothesize that residential moves are systematically related to health.

Few data sets link residential population health and migration. Investigators of intraurban mobility, per se (i.e., without a health and place component) have often analyzed data from the Panel Study of Income Dynamics (PSID). The strength of the PSID is its longitudinal dimension. However, due to the nature and size of its sample, researchers need to aggregate respondents residing in high-poverty areas across the nation, and, thus, cannot focus on geographically defined local environmental exposures. Recent investigations on the longitudinal effects of neighborhood stratification on educational or developmental outcomes in children use this aggregated approach (Jackson and Mare 2007; Wodke et al 2011).

Although its time horizons are proscribed, and, like the PSID, its health data are limited, the U.S. Census yields large sample sizes making estimates highly reliable, and it provides residential population data, uniquely allowing local geographic places to be delineated to observe the nature and extent of moves within, into, and out of specific local areas and their net effect on population health.

\section{Research Questions}

Considering blacks and whites separately, and where population size allows, men and women separately within each race, we explore whether observed geographic patterns of health reflect the influence of health-related migration through these research questions: 
1) What is the extent of residential mobility flows into or out of a diverse set of local areas? If we find little evidence of residential mobility, or in mobility between types of areas with very different health profiles, these findings alone would cast doubt on the healthselective migration hypothesis.

2) To what extent is residential mobility between local areas associated with either healthinduced functional limitations or with socio-demographic characteristics associated with health more broadly, such as age and education? If the associations are insignificant, this would also weaken the plausibility of the health-selective migration hypothesis.

3) If residential mobility and health-induced functional limitation are associated, does such selection affect cross-sectional estimates of local area prevalence of health-induced functional limitation? By comparing local area health profiles in 2000 to what they would have been had no migration occurred, we will garner evidence on the quantitative impact of health-selective migration on cross-sectional snapshots of the health of local populations.

\section{Methods}

The 2000 Census was the first to ask respondents their previous residence down to the ZIP Code level, potentially allowing exploration of short-distance moves or moves between locally defined geographic areas. ${ }^{2}$ Although this ZIP Code information is not included in census data usually available for research, we obtained authorization to analyze it at the Michigan Census Research Data Center (MCRDC). Reporting of our findings is limited to those the Census permits after disclosure review.

\footnotetext{
${ }^{2}$ Current residence has and continues to be coded to even lower levels of aggregation such as census tract or block group. Regarding previous residence, however, in earlier Censuses, the census designated place (CDP), was the smallest level of aggregation. From a research perspective, CDP aggregations are arbitrary. For example, in New York City, Greenwich Village is
} 
Overview and Characteristics of the Study Populations

Our analytic sample comprises the entire non-Hispanic black and non-Hispanic white populations, aged 16 to 64, in 20 geographic aggregates of economically similar ZIP Codes (urban areas) or counties (rural areas). While we focus on these focal areas as points of migration departure or arrival, we study all moves for these areas from or to anywhere in the United States.

Our focal areas are those selected by Geronimus et al. $(1996,1999,2011)$ to explore diversity in the consequences of areal poverty for urban and rural black and white mortality. ${ }^{3}$ Geronimus et al originally selected areas of concentrated poverty of sufficient size for the reliable calculation of mortality schedules, then supplementing them with geographically proximate nonpoor areas. Using census data, we could replicate these areas exactly. By studying focal areas whose mortality profiles were previously described, our findings can inform understanding of mortality differences as well as in census health measures.

These areas represent regional and racial diversity throughout the United States and provide useful comparisons across race, geographic location (ie, northern vs. southern) and urbanicity. Table 1 lists acronyms, economic characteristics and standardized mortality ratios (SMRs)-- directly standardized with reference to the age distribution of the White population nationwide in 2000 according to gender-- for the focal populations in the year 2000 (Geronimus et al. 2011). While the focal black populations generally are less economically advantaged and have higher SMRs than the focal white populations, within the black or white populations, residents of non-poor areas generally have lower SMRs than residents of high-poverty areas and

a CDP, but Harlem is not. City or township of prior residence was the next smallest level and was too large for studying migration between types of neighborhoods within cities. 
those in high-poverty urban areas generally have the highest SMRs, including compared to samerace populations from rural areas with similar or higher poverty levels and lower educational levels.

Geronimus et al. studied only these areas and, for ease of classification, dichotomized them as "poor" or "nonpoor." We retain this classification when studying the focal areas alone, however, because we are studying moves into or out of these focal areas to or from anywhere in the US, we are able to classify places across the US as: low poverty: ( $<10 \%$ of adults in poverty); moderate poverty (10-20\%); high poverty (20-30\%); and very high poverty (over $30 \%$ ), in addition to disaggregating them in terms of urbanicity and region.

Study Data

Study data are drawn from the Sample Edited Detail File (SEDF) of the 2000 Decennial Census. The SEDF represents roughly $16 \%$ of the population and provides average sample sizes for the monoracial ${ }^{4}$ black or white working-age men and women in our populations of just under 5,500 men and just over 6,100 women. The SEDF includes all the long-form records and in greater detail than the public use files. For example, the public use files have confidentiality edits such as top-coding on income or collapsing of detailed categories into broader categories.

In Item 15, the 2000 Census long form asked detailed questions about residential mobility within the United States:

\footnotetext{
${ }^{3}$ Sample size considerations limited their choices to major Northern cities with large black populations or to rural areas around the Mississippi Delta. Major Southern cities had large diverse, black populations, but not concentrated poverty areas of sufficient size. Other Southern rural areas had black populations that, while often poor, were dispersed rather than concentrated.

${ }^{4}$ Nationally, approximately $2 \%$ of respondents reported being multiracial. Given the geographic, age, and socioeconomic patterning of our sample, $2 \%$ is likely to be a generous upper bound on the percent in our focal areas who reported being multiracial .The preponderance of those reporting being multiracial were children younger than 15 years old and Asian Pacific Islanders; while monoracial respondents were disproportionately adult residents of the Deep South, Appalachia, and the midWest (Farley 2002).
} 
(15a). Did this person live in this house or apartment 5 years ago (on April 1, 1995)?

1) Yes, this house -- Skip to 16

2) No, outside the United States — Print name of foreign country, below; then skip to 16.

3) No, different house in the United States.

(15 b). Where did this person live 5 years ago?

Name of City, Town or Post Office

Did this person live inside the limits of the city or town?

Name of county; Name of state; ZIP Code

Response rates in focal areas were high (92\% to 97\%). A trivial fraction of movers into

our study areas migrated from another country (ranging from $0.3 \%$ to $0.9 \%$ ).

We limited our analysis to those who were identified as living in the same dwelling unit five years previous, or, if not, who reported a valid 1995 ZIP Code. We divided our sample into three mobility categories: (1) stayers, (2) movers into our local areas between 1995 and 2000, and (3) movers out of our local areas between 1995 and 2000. Stayers are either residents who did not report a move between 1995 and 2000, or residents who reported a move but whose reported 1995 ZIP Code or county fell within the 2000 focal area. Movers in are those whose 1995 ZIP Code/county fell outside the 2000 focal area. Movers out are those whose 1995 ZIP

Code/county fell within the focal area, but who are no longer living in the area in 2000.

The 2000 Census long form asked respondents two sets of health-related questions probing functional limitations induced by chronic health conditions. ${ }^{5}$ We count a respondent as limited if they answered yes to any of these questions ${ }^{6}$ :

\footnotetext{
${ }^{5}$ Because the health measures were reported in 2000, we do not know whether movers between 1995 and 2000 were in poor health at the time they moved. This would be highly problematic if our primary research interest was in the causal impact of health on migration. However, our interest lies in whether migration patterns influence cross-sectional snapshots of the health profiles of study areas. We can address research questions 3 and 4 about the potential association between residential mobility and health limitations knowing only the health of migrants and non-migrants in 2000, because we are interested in comparing the health profile of areas in 2000 to what they would have been had no migration occurred.

${ }^{6}$ We conducted all analyses first by combining answers to all of these questions, counting a person as health limited if they report any impairment or disability. We then experimented with alternative coding schemes involving subsets of these questions. We were particularly interested in schemes excluding the work disability question, out of concern that responses might differ systematically with local labor market variations. Disability levels are somewhat higher when we include the work disability question, but patterns of results are robust to our choice of disability measures.
} 
(16) Because of a physical, mental, or emotional condition lasting 6 months or more, does this person have any difficulty in doing any of the following activities:
a) Learning, remembering or concentrating?
b) Dressing, bathing or getting around inside the home?
c) Going outside the home alone to shop or visit a doctor's office?
d) Working at a job or business?

(17) Does this person have any of the following long-lasting conditions:

a) Blindness, deafness or severe vision or hearing impairment?

b) A condition that substantially limits one or more basic physical activities such as walking, climbing stairs, reaching, or lifting?

\section{Measurement Issues}

\section{ZIP code Data}

As the first researchers to use ZIP Code data to identify residential mobility patterns, we tried to assess their validity (Geronimus, Bound and Ro 2010). We found that when respondents report previous ZIP Codes of residence, they generally report these items accurately: only 2\% of reported ZIP Codes were invalid, while an additional 2\% were inconsistent with other data in the file (e.g., county of residence). Although the census imputed values when 1995 county or state data were missing, no imputations were made for ZIP Codes.

Table 2 shows response and imputation or missing rates for each of the migration questions by area type. The vast majority of those who move dwelling units reported both their previous state and county of residence. However, 20-30\% of movers did not report ZIP Code data for previous residence. Moreover, when we estimated logit regressions on the sample of individuals who would have been asked to report their ZIP Codes of previous residence based on their answers to earlier questions, we found men, the unemployed, and the disabled were each about 20\% less likely to report their previous ZIP Code than were their counterparts. We also found that those who made moderate or long-distance moves were about $60 \%$ less likely to 
report previous ZIP Codes than were short- distance movers. However, long-distance moves

were substantially less common than short-distance moves; and when they did occur, we could identify them using state or county of previous residence when ZIP Code was missing. ${ }^{7}$ Despite non-randomness, sensitivity analyses described in the results suggest that our conclusions are robust to excluding those with missing ZIP code information.

\section{Health Indicator}

The health-induced functional limitation data are the only health indicators available in the census. Although they are neither sufficient for medical diagnosis of specific conditions, ${ }^{8}$ nor fully representative of all aspects of health that might be associated with either place or residential migration, there is reason to believe that the census measures are sufficient for the analytic objectives of this study (Brimblecombe et al. 1999, 2000; Hayward and Heron 1999; Geronimus et al 2001 Norman et al, 2005). ${ }^{9}$ Self-reported measures of health are highly correlated with clinical measures of morbidity and predictive of subsequent death, health care utilization, and labor market behavior (Idler and Benyamini 1997; Manning, Newhouse and Ware 1982). Researchers have also found that conceptually distinct self-reported health and

\footnotetext{
${ }^{7}$ In the 2000 population we could have included those who were living in the local area as of 2000, had moved since 1995 but had missing zip codes. Rather than doing this, we chose to exclude movers with missing or invalid zip codes to make our measurement of the health profile of the population in 2000 more comparable to our measurement of the population in 1995. Essentially, our procedure involves comparing the health profile of those who move in to those who move out. If the health profiles of these two populations are quite different or if the size of these two populations are quite different, then our estimates will show migration affecting the health profile.

${ }^{8}$ For those interested in the severity of functional limitations or disabilities, per se, legitimate concerns have been raised about the validity of the census impairment and disability items, which are based on a mail-back questionnaire, are sometimes filled out by proxy respondents, and contain only general questions rather than specific measures of ADLs or IADLs collected in some surveys. Andresen et al. (2000) found that responses to the more global census questions did not correspond precisely to responses to narrow questions about specific ADLs or IADLs. This finding is neither surprising nor particularly pertinent to our analysis. For us, the important question is whether differences across areas in responses to census questions accurately reflect differences across areas in the age-specific health status of the respective populations.

${ }^{9}$ Hayward and Heron (1999) and Geronimus et al. (2001) have used census disability measures successfully for similar analytic purposes. British studies of the role of selective migration in understanding the sources of the geographic distribution of the healthy population across local areas (Brimblecombe et al. 1999, 2000; Norman et al, 2005) used a combination of vital statistics data and self- reported functional limitation measures similar to those available in the census. Findings using the different measures were similar, supporting the notion that, in the context of studies such as our own, self-reported functional limitation data allow for valid inferences with respect to health selective migration.
} 
chronic condition measures -- including global health measures such as these census measures, or Activities of Daily Living (ADLs), and Instrumental Activities of Daily Living (IADLs) -- are highly correlated with one another (Johnson and Wolinsky 1993). Regarding population contrasts, we note that general patterns of health-induced limitations by age and race in the 2000 Census are consistent with what is known about age and racial patterns of disability from other sources. $^{10}$

\section{Statistical Analysis}

We took a two-step approach to address research question 1 about the extent, nature and types of moves made within, into, and out of the focal areas to or from anywhere in the nation. First, we tracked the percentage of each focal population who moved dwelling units between 1995 and 2000. Second, we classified movers as those who moved within the focal area, those who moved out of the area after 1995, and those who moved into the area by 2000. We tracked whether movers stayed within a specific focal area, moved between similar local areas anywhere in the United States (e.g., from one poor urban area to another), or moved across area types in the United States (e.g., from poor to nonpoor areas; from poor urban to poor rural areas).

To address research questions 2 and 3 on the potential association between residential mobility and health limitations, we first compared the health-induced limitation rates of those who moved into or out of our focal areas to those who remained in them. Additionally, we estimated the probability that those living in each of our focal areas in 1995 moved out by 2000 as a function of their health-induced functional limitation status in a series of logistic regression

\footnotetext{
${ }^{10}$ Limitation rates rise with age. Older Americans are more likely to suffer multiple limitations than younger ones. African Americans have higher impairment and disability rates than whites, with racial disparities most pronounced in young through middle adulthood. Limitations in young through middle adulthood are disproportionately work-related limitations, with those in
} 
models that ultimately also controlled for age and education. In a similar fashion, we estimated the probability of moving into one of our focal areas between 1995 and 2000. These estimates allowed us to determine whether health-induced limitation and residential mobility are associated, and the extent to which age and education affect this association.

The net effect that migration might have on resident populations will depend on both the characteristics of movers and the frequencies of moves. To measure the extent to which differential residential mobility affected the geographic distribution of the healthy and unhealthy populations, we calculated the geographic distribution of health status of focal area residents by (1) residence as of 1995 and (2) current residence in 2000. A comparison between (1) and (2) provides a direct measure of the effect of residential mobility on the geographic distribution of the healthy population over the five-year time horizon.

\section{Results}

Migration

Figure 1 displays that between one-quarter and almost one-half of the 2000 residents of each focal area had moved dwelling units since 1995. The vast majority of the movers relocated short distances. For example, of the Harlem residents who moved between 1995 and 2000, 47\% stayed within the same Harlem focal area, 64\% moved into Harlem from another part of the same county (Manhattan), and 85\% of those who moved into Harlem came from another part of New York state (Figure 1). Similarly,76\% of those moving out of Harlem stayed within New York state - 38\% stayed in Harlem, 47\% stayed in Manhattan, and 65\% stayed in the same metropolitan statistical area (MSA) .

mobility and personal care increasing in magnitude in old age. Each of these patterns is consistent with expectations based on 


\section{Moves between Urban and Rural or between Northern and Southern Areas}

Tables 3 (movers in) and 4 (movers out) provide information on the nature of moves. We find little evidence of migration between northern urban and southern rural local areas. The vast majority of movers into or out of the black northern urban poor areas move within the same MSA; most others move from or to another northern MSA or, in some cases, to a southern MSA. For example, $87 \%$ of movers in to Eastside Detroit and $88 \%$ of movers out of the area moved within the same MSA. While we find some evidence of movement between rural and urban areas within the same region (north or south), the number who move across regions to or from a highpoverty rural area is often too small to disclose (e.g.,Harlem movers to a rural area). Similarly, the vast majority of white residents of high-poverty urban areas move within the same MSA and virtually all stay in a northern MSA. For example, $78 \%$ of Cleveland movers out went to the same MSA and only $4 \%$ went to a southern MSA.

Among movers into or out of high-poverty southern rural areas, the largest share moved to or from a southern MSA. For example, in East North Carolina, $42 \%$ of movers in came from and $70 \%$ of movers out went to a southern MSA. The stream between southern rural and urban areas is substantial in both directions (to and from) and for whites and blacks. Small percentages of black populations move between southern rural areas and virtually none moves between a southern rural and a northern rural area. White residents of high-poverty rural areas move into or out of other rural areas at a greater rate than blacks, but they primarily move between southern rural areas.

The vast majority of movers into and out of non-poor urban areas, black or white, moved within the same MSA. While small percentages moved between a northern and southern MSA,

what is known about age and racial patterns of health-induced limitations from other sources. 
virtually none (undisclosed - $<5 \%$ ) moved between an urban focal area and a rural area (north or south).

Areal Economic Mobility

Regarding moves between areas with different poverty levels, we see patterns that vary considerably for black and white populations. Among black residents of high-poverty urban areas who moved, about half or more moved between high-poverty urban areas and up to $95 \%$ moved to or from moderate or high-poverty areas. The percent moving to or from low-poverty areas never exceeded 19\% (movers out of Harlem), and was 10\% or less in many cases (movers into Harlem, Eastside Detroit, Southside Chicago and Watts). In stark contrast, the vast majority of whites who moved to or from urban high-poverty areas moved to or from low-poverty areas. Roughly $85 \%$ of those who moved out of white urban high-poverty areas moved to a lowpoverty area, while $70-80 \%$ of movers into the high-poverty white urban areas came from lowpoverty areas.

The economic patterns of residential mobility for the rural areas were similar, in that most of the movers in and out of the high-poverty black areas made moves to and from similar poor areas while the white rural areas saw more areal social mobility in their migration patterns. The majority of black movers out from rural high-poverty areas went to moderate or other highpoverty areas and no more than $20 \%$ moved to a low-poverty area. For example, $75 \%$ of East North Carolina movers out went to moderate or high-poverty areas and only $19 \%$ went to a lowpoverty area. In contrast, a substantial proportion of whites in rural high poverty areas (37-74\%) moved to low-poverty areas, and a very small percentage moved to high-poverty areas, except for those moving out of the Appalachian Kentucky area, among whom about 22\% moved to 
another high-poverty area (still a smaller percentage than found for blacks moving from highpoverty rural areas).

Only $10 \%$ of black rural movers in to high-poverty rural areas came from low-poverty areas, while up to $80 \%$ of white rural movers in to high-poverty rural areas came from lowpoverty areas. Most black rural movers in to high-poverty rural areas came from other highpoverty areas, while the percentage of white movers in from high-poverty areas is so small that we cannot disclose it.

Among movers to or from the non-poor urban areas, black-white variation in origin and destination is also apparent. Unlike black movers from high-poverty areas, who tended to make socioeconomically lateral moves, the majority of black movers out of non-poor areas in 1995 (60-82\%), moved to higher poverty areas by 2000 , with a smaller percent moving to another low-poverty area. In striking contrast, the vast majority of white movers out from non-poor areas (83-92\%) move to other low-poverty areas, with only 8-17\% moving to less well-off areas.

With the exception of movers in to the Northwest Detroit area, black movers in to the non-poor urban areas come primarily from moderate or high-poverty areas. In the case of Northwest Detroit, 70\% come from low-poverty areas and about 30\% from high-poverty areas. Unlike most black movers to urban non-poor areas, the vast majority of white movers into urban non-poor areas come from other low-poverty areas (78-90\%). Thus, unlike their black counterparts, the vast majority of white movers to or from non-poor urban areas move to or from other low-poverty areas.

What do the findings addressing research question 1 say about the potential for healthselective migration as a contributor to the area-specific mortality differentials found in previous research? We found a considerable amount of residential mobility, especially among blacks in 
northern urban areas, yet, this appeared to be migration from one area of concentrated poverty to another. This fact would seem to argue against the plausibility of health-selective migration being an important determinant of observed geographic differences in health among poor blacks. We found at least as much upward mobility among blacks living in poor rural communities as in poor urban areas. For selective migration to explain the large mortality differential found between focal areas in the urban north and rural south, the northern upward outmigration would have to be substantially more health-selected than the rural southern upward outmigration. The similar mobility patterns we observed between the black urban high-poverty and black rural high-poverty areas suggest that documented urban-rural differences in mortality are unlikely to be importantly influenced by health-selective migration - either urban-rural or north-south. Still, both socioeconomic and geographic mobility occurred often enough that we cannot use migration streams alone to dismiss the possibility that health-selective migration might be having an impact on some geographic health profiles.

Migration and Health

Table 5 presents sex-specific age-standardized health-induced disability prevalence for each local area stratified by residential mobility status - stayers, movers out, and movers in between 1995 and 2000. With two exceptions - Watts movers in and Bronx movers out -- black men who moved in or out of any focal area had the same or lower disability prevalence than those who stayed. Differences between black male movers and stayers were generally larger in the high-poverty focal areas than in the non-poor ones, with the largest disability rate difference found in Eastside Detroit - 8 percentage points higher for stayers versus movers out. Differences between black male movers out and stayers were statistically significant in four areas, Harlem, 
East Detroit, Northwest Detroit, Southwest Chicago, and marginally significant $(\mathrm{p}<.10)$ in Black Belt Alabama. Disability differences between black male stayers and movers in were marginally significant in East North Carolina, Black Belt Alabama, and Delta Louisiana.

Black women movers in or movers out of poor areas also usually had the same or lower disability rates than stayers. Unlike for men, black women movers in nonpoor areas tended to have lower disability rates than stayers when they were in the movers out category, but higher disability rates when they were movers in, although the differences were small for both move types.

White men movers in or out generally had lower disability rates than stayers in all areas, though the differences were usually insignificant except for Detroit, where white male movers had a 9 percentage point lower disability rate than white male stayers. White women showed a less consistent pattern. In most cases we see no statistically significant differences between movers and stayers, and where we do, movers have lower disability rates than stayers.

\section{Residential Mobility, Age and Education}

Table 6 presents sex-specific age-standardized high school graduation rates ${ }^{11}$ for each focal area stratified by residential mobility status between 1995 and $2000 .^{12}$ For every focal area, the same or a higher percentage of black male movers (in or out) were high school graduates than were stayers. This differential was generally large and statistically significant in the high-poverty areas, but not in the non-poor areas. In several cases in high-poverty areas, graduation rates were about 10 percentage points higher among movers than among stayers, and

\footnotetext{
${ }^{11}$ We focus on education rather than income, because education is a less volatile measure of socioeconomic position and, unlike income, likely to be a permanent feature of an adult, and less subject to the threat of reverse causality.

${ }^{12}$ Here and in most of the rest of the paper we age standardize because there are clear health and education differences across age groups, reflecting a combination of age and cohort effects on these outcomes. We do not also standardize on education because educational differences across areas could reflect differential migration.
} 
movers out of poor rural areas had graduation rates that were 11 to 20 percentage points higher than those of stayers.

The patterns for black women in poor local areas were similar to black men’s, though more muted. In non-poor urban areas, black women stayers were generally as likely to be high school graduates as movers in, while black women movers out were often more likely to be high school graduates than stayers, with the difference statistically significant in two areas (Northwest Detroit, Southwest Chicago).

White men in urban or rural high-poverty areas who were movers had substantially greater high school graduation rates than did stayers. In non-poor urban areas, differences between movers and stayers were small and the direction was inconsistent. Patterns for white women were generally similar in all areas, but education differences between stayers and movers were smaller than for white men and less likely to be statistically significant.

\section{Logistic Regression Results}

In Table 7, we report the results of our race- and sex-specific regressions of the odds of moving out of and the odds of moving in to high-poverty urban, high-poverty rural, and non-poor urban between 1995 and 2000. Explanatory variables include dummies for age (referent=16-24 years), high school graduate, college graduate (referent = less than high school education), focal area of residence (in 1995 for odds of moving out; in 2000 for odds of moving in), and disability status.

As a general rule, we find that the odds of moving between 1995 and 2000 were higher in the younger and the more-educated groups than in the counterparts. Net of age, those who did not complete high school usually had the lowest odds of moving, and those who only completed high school had lower odds of moving than those with a college education, with the odds of 
moving for college graduates significantly larger in many cases. Exceptions to this were seen among black women who, for example, exhibited little difference by education in their odds of moving into a non-poor urban area.

We often saw lower odds of moving among those with health-induced disability, however the differences were smaller than seen for age or education, and were attenuated by controls for age and education. In fact, in high-poverty rural populations and in white non-poor areas, the odds of moving out were insensitive to disability status net of age and education. Overall, selection on education is larger and stronger than on health-induced disability, per se, fully accounting for the age-adjusted relationship between migration and disability status in these cases.

Women showed no difference, net of age and education, in their odds of moving into focal areas by disability status, with the exception of urban poor black women, for whom the odds were 14\% lower among the disabled (compared to 32\% and 101\% higher for high school and college graduates, respectively). Moving into urban non-poor areas was insensitive to education or disability, net of age. Among white women in urban high-poverty areas, the odds of moving in were 19\% higher for the disabled (but 97\% and 200\% higher for high school and college graduates, respectively).

For men, many groups showed no difference by disability status in the odds of being movers in, net of age and education, with slightly reduced odds found for disabled black men in rural high-poverty areas, disabled black men in urban non-poor areas, and disabled white men in urban high-poverty areas. Here, too, the odds of moving in associated with health-induced disability were generally dwarfed in size by the impact of education. 
Using multinomial logit models we found no evidence that disability status affected the nature of either the origin from which or the destination to which an individual moved (not shown).

Impact of Selective Migration on Estimates

The findings to this point, suggest that residential mobility is selected on factors associated with health (age and education) and sometimes on health-induced disability net of age and education, with some signs of variation in the nature and degree of selectivity by gender, area type, and race. Does such selection affect cross-sectional estimates of local area disability prevalence?

In Table 8 we present estimates of health-induced disability prevalence by sex in each focal area in 1995 and 2000 age-standardized to the U.S. black or U.S. white age distributions. The “1995” values represent the fraction suffering health-induced disabilities among those who were living in each focal area as of 1995 - that is, as if no residential mobility had occurred between 1995 and 2000. The “2000” values represent the fraction suffering health-induced disabilities among the actual population living in each focal area in 2000.

Differences in age-standardized estimates of disability prevalence based on the 1995 versus the 2000 population of each focal area are small. For black men or black women, the two estimates are within about 1 percentage point in all areas. This is also the case for white men and white women with the notable exception of Detroit, where estimated disability prevalence is higher for the 2000 than the 1995 population, by 2 points for men and 3 points for women. The only statistically significant differences are seen for black women in Northwest Detroit and for white women and white men in Detroit. 
In most areas the lower disability rates for the movers in and the movers out compared to the stayers seem to approximately cancel each other out, leaving estimates based on the 1995 and 2000 populations roughly equivalent. In the three Detroit cases where disability rates differed by year, the rates were always higher when using the 2000 definition of the population. A combination of factors can account for this. First, in the case of the white Detroit populations, the groups moving out were substantially larger than those moving in. Thus, for example, 37\% of the white women residing in Detroit in 1995 had moved out by 2000. In contrast, only 13\% of white women living in our Detroit area in 2000 had moved in between 1995 and 2000. For white men, 33\% of 1995 Detroit residents had moved out while only 13\% of 2000 Detroit residents had moved in during the previous five years. Given these disparate flows, even if the movers in had lower disability rates than the movers out, the flows would not have canceled each other out and the disability rate would still have been higher in the 2000 Detroit population. In addition, for black women in Northwest Detroit and white women in Detroit, the limitation rates for movers in were, if anything, marginally higher than the limitation rates for the stayers.

One concern about using two snapshots in a five-year period might be that health differences between those who had and had not moved out of areas might diverge, but not in the window studied. This would be more likely if net outmigration favored higher or lower SES groups. To check the plausibility of this possibility, we looked at the educational attainment of our 20 populations defined in terms of their 1995 and 2000 residential locations (not shown). Differences in education between the populations defined in terms of their 1995 and 2000 populations are small. Where meaningful and statistically significant differences do exist, net migration out of poor urban areas was as likely to favor the less well educated as the better educated. In contrast, net migration out of poor rural and non-poor urban populations tended to 
favor the better educated. These are not the patterns one would have expected if upward mobility accounted for observed health profiles.

\section{Sensitivity Analyses}

To check the sensitivity of the results to the exclusion of those cases missing ZIP Codes of previous residence, we compared our tabulations of the health profiles of the 2000 populations to tabulations that included the movers with missing ZIP codes. In each case, we know the individual was living in the area in 2000, but do not know if they moved in from another area or changed dwelling units within the same area (i.e., whether they were movers in or stayers). ${ }^{13} \mathrm{We}$ made two extreme assumptions in separate sensitivity analyses: first, we assumed all movers with missing ZIP Codes had moved from outside the area (were movers in); and second, that all movers with missing ZIP Codes moved within the local area (were stayers). ${ }^{14}$ Changing our definition had no measureable effect on the characteristics of the movers, regardless of whether we focus on the fraction with a health-induced disability or with a high school diploma.

Similarly, we did a robustness check using available information on previous county and state. So, for example, when individuals did not report a ZIP Code, but did report a state of previous residence, we determined whether or not they moved across or within states. If they reported neither a previous ZIP Code nor state, we made two extreme assumptions, in one case assuming all these individuals moved between states and in the other that none did. Using this method, the bounds we calculate for the fraction of moves that involve moving from out of state

\footnotetext{
${ }^{14}$ Our strategy is in line with the kinds of strategy suggested by Horowitz and Manski (1995).
} 
were usually quite similar to the fractions reported. ${ }^{15}$ Thus, as a general point, our analyses provide reassurance of data validity to other researchers interested in using the ZIP Code of previous residence data available in the census for analytic purposes related to short-distance moves or moves between local areas (whether or not their analytic interests are health related).

\section{Discussion}

Using 2000 Census data, we have shed new light on the important question of whether population dynamics of residential areas may be a competing explanation to place or static compositional effects for understanding observed associations between health and place. We were able to analyze migration streams at a more fine-grained level than was previously possible. We found little evidence that observed migration affected the overall distribution of the healthy or unhealthy populations across our focal study areas. While it is often the case that those who moved out of focal areas tended to be younger, more highly educated, and in better health than those who stayed, it is also true that those moving in tended to be younger, more highly educated, and in better health. These two residential mobility streams appear to approximately cancel each other out, leaving cross-sectional estimates of local population health stable.

The notable exception to this regularity was Detroit, where small but statistically significant differences were seen depending on which year’s snapshot was considered, among white men and women in the high-poverty areas, and black women in the non-poor area.

\footnotetext{
${ }^{15}$ Thus, for example, we calculated the average maximum possible error for those living in one of our four poor black urban areas to be $10 \%$. Doing a similar analysis for county again showed bounds that were qualitatively similar to the fraction reported in Figure 1. In this case we calculated the average maximum possible error for those living in one of our four poor black areas to be $12 \%$. Extreme bounds for whether individuals moved from within the same local area were, for obvious reasons, less tight, but were still informative. For eample, using records with valid zipcode information, we calculated that $53 \%$ of those in Harlem who had moved dwelling units between 1995 and 2000 had moved into Harlem from someplace else, with most of these moving from within Manhattan. Including those with missing zipcodes in the analysis and using all reported information, we can bound the fraction of movers who moved in from outside of Harlem to between 49 and 71 percent. While this range is not as tight as we might have liked, it remains clear that most moves are short distance moves.
} 
Although white movers in or out were as or less likely to be disabled than stayers, the streams in the two directions were of vastly different magnitude and did not cancel each other out in terms of their effect on the estimated percent of the population suffering health-induced functional limitations. In addition, for black women in Northwest Detroit, disability rates for movers in were marginally higher than for stayers, perhaps reflecting the movement of poor blacks from the central cities to inner-ring suburbs - a characteristic of poverty deconcentration efforts (Jargowsky 2003). These exceptions suggest that health and place researchers using crosssectional estimates should consider whether a recent substantial in- or out-migration has occurred in a specific area that was not countered by a comparably sized migration in the opposite direction. If so, their estimates of the association between health and place may be badly biased. Investigators have found blacks less likely than whites to translate economic resources into residential movement to better resourced, safer, or higher status communities (Alba et al. 1994; Charles 2003; Crowder 2001; Massey and Denton 1987; Tolnay 2003 ). Structural barriers are key to this relative lack of upward residential mobility (Charles 2003; Crowder et al. 2012; Massey et al 1994; Tolnay 2003). Our findings are generally consistent with these earlier studies as we saw about $85 \%$ of whites who moved out of high-poverty areas move to lower poverty areas, while this was only true for $10-20 \%$ of blacks. Also, consistent with our findings of more muted associations between age, education, health and residential mobility for women than men, Halliday and Kimmitt (2008) found a relationship between health and mobility among men, but not women, although spouse's health affected the mobility of married women.

One might wonder whether documented return migration of black populations from the North to the South (Frey 1998, 2001) might influence the size or direction of differences in 
excess mortality between Northern urban v. Southern rural high-poverty black areas. However, we found similar results to earlier studies indicating black North to South flows have typically been from urban to urban areas and are, to some extent, concentrated among middle-class blacks (Hunt et al, 2008). As such, return migration does not appear relevant to the question of why high-poverty urban populations experience greater excess mortality than high-poverty rural ones.

While our estimates of the prevalence of health-induced disabilities generally do not suggest that health and place effects are spurious - that they are simply an artifact of selectivehealth migration -- our findings that much movement into and out of the focal study areas is significantly associated with health suggests that investigators interested in understanding the causal effects of place on health face a complicated challenge. The substantial residential mobility across the study populations between 1995 and 2000 - ranging from over one-quarter to almost one-half of each population -- mitigates against attributing the high rates of mortality found in some areas to the long-term exposure of local residents to specific neighborhood environmental characteristics, especially mortality from diseases with long latency periods. The primary causes of death that persistently account for important variation in nonelderly adult excess mortality across U.S. population types -- such as cardiovascular diseases, cancer, and HIV/AIDS - are such diseases (Geronimus et al 2011). The possibility of a causal relationship between unique aspects of specific places and health might still pertain to health conditions with very short latency periods, to ones - even with long latency periods - if they are easily aggravated by short-term environmentally structured changes (e.g. changes in diet or exercise owing to restricted access to healthy foods or safe and inviting exercise spaces; or aggravated impacts of smoking owing to increased environmental air pollution or lead), or to differential access to health services by place, if the latter affects the rate that injuries or incident cases of 
disease, acute or chronic, progress into disabilities or become case fatalities. Conceptually, these are secondary or tertiary prevention pathways distinct from the pathway in which physical exposures inherent to specific geographic places result in chronic health problems after a long latency period.

To the extent that we found migration did not affect the health profiles of focal areas, one plausible explanation would be that most moves tended to short-distance migration or that, especially for blacks, between similar area types in terms of poverty status, urban or rural, and northern or southern location. It is possible that the environmental characteristics of specific types of local areas (high-poverty urban or high-poverty rural) are similar enough that even moving between specific areas of the same type, individuals are exposed over long periods to the same noxious etiologic agents. Another possibility is that the frequent experiences of loss or disruption that may be implied by the frequency of moves we observed may, in itself, impact health and well-being, and be a common feature of disadvantaged areas (Fullilove 2004; Keene and Geronimus 2010; Keene, Padilla and Geronimus 2010; Wallace and Wallace 1998) In addition to threatening material and environmental exposures, the psychosocial stressors inherent in lower structural positions or the contingencies of social identity associated with being black, urban, or poor in the U.S. may have adverse health effects that track with structural location, regardless of specific ZIP Code. Cues to cultural oppression and structurally constrained life chances may trigger repeated or chronic episodes of vigilance, rumination, or physiological stress process activation with concomitant wear and tear on important body systems (James 1994; Iznicht and Shmader 2011; Geronimus and Thompson 2004; Geronimus et al 2006; Geronimus 2013). 


\section{Limitations}

Because we used census data to estimate the impact of health-related migration on associations between health and place, we were limited to the use of functional limitation as the health indicator and to a five-year period for residential mobility. Ideally, we would follow individuals’ residential mobility from childhood through adulthood. How might the results differ? One can imagine residential environmental impacts could have immediate, mediumterm, or long-term health implications; and that any long-term health implications may result from cumulative environmental impacts over the life course. ${ }^{16}$ The 2000 Census data provide us two residential snap shots of each individual, in 1995 and 2000. Some of these individuals were youth or young adults in 1995, others were older. The five-year window allows us to capture immediate environmental impacts, including ones that interact with chronic disease progression to disability or excess mortality such as access to health care. Regarding longer-term health implications, we might very well see larger differences if we were able to observe individuals over a 10-, 20-, or 30-year period. Still, if there is important health-selective migration, then, in general, we would expect to observe some evidence of this within just the five-year window.

We note an instance in which the five year window could be misleading. If some poor young adults are upwardly socially mobile and move out of high-poverty neighborhoods as a result, their health trajectory may differ from their childhood neighbors who were not upwardly

\footnotetext{
16 These might include from the delayed expression of epigenetic modifications resulting from previous environmental conditions, including childhood and prenatal contexts. If life-threatening disease onset is a direct product of "fetal programming," as some hypothesize (Gluckman et al 2008), then short of longitudinal data beginning at conception and continuing through midlife, no time horizon would be sufficiently long to capture these effects. However, evidence is weak that any prenatal conditions are more important to adult and later life health than post-uterine environmental conditions (Geronimus 2013).
} 
mobile. ${ }^{17}$ Such health differences might not emerge right away. Our consideration of educational characteristics of movers compared to stayers provides some evidence, albeit suggestive, that upward mobility is unlikely to be a serious threat to the validity of the results using the five-year window.

To our knowledge these are the best currently available data for beginning to address the question of the degree to which cross-sectional associations between health and local residential place may be biased by failure to take into account the dynamic nature of local populations. Additional data are needed - to be collected or made available - that will allow researchers to dig deeper into the associations between health, place, and residential mobility. The ideal dataset would have enormous sample sizes that are place-based or can be geocoded, would follow people longitudinally through their lives, and would include reliable health measures.

Administrative data would be one route. For example, social security records linked to death certificates have the potential to tell us where people were working at any point in their working lives, a proxy for place-based exposures as well as a way to track presumed residential mobility. One could imagine various other administrative data sets such as welfare records, Medicaid records, or Medicare records that would offer needed information as well. Any one of these data sets would miss groups of people -- those who have never worked, those who are not recipients of safety net programs - and matching administrative records to death certificates is imperfect. Yet, if researchers could overcome the confidentiality barriers to accessing these data, and perhaps triangulate from different data sources, major strides might be made.

While subject to noted limitations, this study is the first to attempt to address a critical question in the burgeoning health and place literature. We find no evidence that excess mortality

\footnotetext{
${ }^{17}$ Note that depending on race/ethnicity, gender, and nativity status, the magnitude or direction of this difference would vary
} 
in US high-poverty urban relative to high-poverty rural areas results from selective migration. Selective migration does not appear to bias cross-sectional estimates in most instances, but the Detroit results suggest investigators cannot take this as axiomatic. Instead, consideration of whether a specific area studied has been subject to a recent, sizeable net one-way migration -- in or out -- that was racially or socioeconomically structured is indicated for properly interpreting estimates. Our findings provide reassurance that quantitative cross-sectional estimates of the distribution of the healthy and unhealthy population can be used to target medical and social services where they are most needed. Yet, their failure to point in a single etiological direction leave important sociological, epidemiological, and public policy questions unanswered regarding the fundamental and proximate causes of geographic disparities in health. Those designing studies to address such questions are advised to consider the implications of residential mobility dynamics in drawing valid inferences from cross-sectional data.

(Colen et al 2005; Pearson 2008, Viruelle-Fuentes 2007). 


\section{Acknowledgments}

We are grateful for funding from the Eunice Kennedy Shriver National Institute of Child Health and Human Development (grant \# R21 HD056307) and the National Institute of Aging (grant 5 T32 AG00221), as well as to the Center for Advanced Study in the Behavioral Sciences at Stanford University and the University of California’s President's Postdoctoral Fellowship program. Support for this research at the RDC from NSF (ITR-0427889) is also gratefully acknowledged. We also thank seminar participants at the University of Minnesota RDC and three anonymous reviewers for helpful comments on earlier versions of this paper.

DISCLAIMER: Any opinions and conclusions expressed herein are those of the author(s) and do not necessarily represent the views of the U.S. Census Bureau. All results have been reviewed to ensure that no confidential information is disclosed 


\section{References}

Alba, R.D., Logan, J.R., \& Bellair P. (1994). Living with crime: The implications of racial and ethnic differences in suburban location. Social Forces, 73, 395-434.

Andresen, E.M., Fitch, C.A., McLendon, P.M., \& Meyers, A.R. (2000). Reliability and validity of disability questions for US Census 2000. American Journal of Public Health, 90(8), 1297-1299.

Beard, J. R., S. Blaney, et al. (2009). Neighborhood Characteristics and Disability in Older Adults.The Journals of Gerontology Series B: Psychological Sciences and Social Sciences 64B(2): 252-257.

Brimblecombe, N., Dorling, D., \& Shaw, M. (1999_. Mortality and migration in Britain, first results from the British Household Panel Survey. Social Science \& Medicine, 49(7), 981988.

Brimblecombe, N., Dorling, D., \& Shaw, M. (2000). Migration and geographical inequalities in health in Britain. Social Science \& Medicine, 50(6), 861-878.

Bureau of the Census. 2000. Website: http://www.census.gov/main/www/cen2000.html

Charles, Camille Z. 2003. “The Dynamics of Racial Residential Segregation.” Annual Review of Sociology 29:167-207.

Cozier, Y.C., Palmer, J.R., Horton, N.J., Fredman, L., Wise, L.A., \& Rosenberg, L.. (2007). Relation between neighborhood median housing value and hypertension risk among black women in the United States. American Journal of Public Health, 97(4), 718-724. 
Crowder, K.D. (2001). Racial stratification in the actuation of mobility expectations: Microlevel impacts of racially restrictive housing markets. Social Forces, 79, 1377-1396.

Crowder, K., Pais, J., et al. (2012). Neighborhood Diversity, Metropolitan Constraints, and Household Migration. American Sociological Review 77(3), 325-353.

Crowder, K.D., Tolnay, S.E., et al. (2001). "Intermetropolitan migration and locational improvement for African American males, 1970-1990." Social Science Research 30(3), 449-472.

Davey Smith, G., Hart, C., Watt, G., Hole, D., \& Hawthorne, V. (1998a). Individual social class, area-based deprivation, cardiovascular disease risk factors, and mortality: The Renfrew and Paisley study. Journal of Epidemiology and Community Health, 52,399-405.

Davey Smith, G., Shaw, M., \& Dorling, D. (1998b). Shrinking areas and mortality. The Lancet, 352(9138), 1439-1440.

Diez-Roux, A.V., (2001). Investigating area and neighborhood effects on health. American Journal of Public Health, 91(11), 1783-1789.

Diez-Roux, A. V., F. J. Nieto, et al. (1997). "Neighborhood Environments and Coronary Heart Disease: A Multilevel Analysis." American Journal of Epidemiology 146(1): 48-63.

Diez-Roux, A.V., (2007). Neighborhoods and health: where are we and were do we go from here?: Rev Epidemiol Sante Publique. 2007 February ; 55(1): 13-21.

Dressler, W.W., Oths, K.S., \& Gravlee, C.C. (2005). Race and ethnicity in public health research: Models to explain health disparities. Annual Review of Anthropology, 34. Palo Alto, CA: Annual Reviews. 
Elo, I., \& Preston, S. (1996). Educational differentials in mortality: United States, 1979-85. Social Science and Medicine, 42, 47-57.

Falk, W. W., Hunt, L.L., et al. (2004). Return Migrations of African-Americans to the South: Reclaiming a Land of Promise, Going Home, or Both? Rural Sociology 69(4), 490-509. Farley, R. (2002). Race Reporting in the Census of 2000: How Do Multiracial Groups Compare to Monoracial Groups on Key Characteristics? PSC Research Report Report No. 02-516, Institute for Social Research, University of Michigan.

Findley, S. (1988). The directionality and age selectivity of the health-migration relation: Evidence from sequences of disability and mobility in the United States. International Migration Review, 22(3), 4-29.

Fitzpatrick, K., \& LaGory, M. (2010) Unhealthy Cities: Poverty, Race, and Place in America. Second (Ed.), London, UK: Routledge.

Freedman, V.A., Grafova, I.B., \& Rogowski, J. (2011). Neighborhoods and Chronic Disease Onset in Later Life. American Journal of Public Health, 101(1), 79-86.

Frey, W.H. (1998). Black migration to the South reaches record highs in 1990s. Population Today, 26(2), 1-3. (Population Reference Bureau, Washington DC. Reprint No. 561).

Frey, W.H. (2001). Census 2000 shows large black return to the South, reinforcing the region's “White-Black” demographic profile. PSC Research Report, 01-473.

Fullilove, M. (2004). Root Shock: How Tearing up City Neighborhoods Hurts America and What We Can Do about It. New York, NY: Balantine Books.

Galea, S., \& Vlahov, D. (2005). Handbook of urban health: Populations, methods, and practice. New York, NY: Springer. 
Geronimus, A.T. (1992). The Weathering Hypothesis and the Health of African American Women and Infants. Ethnicity and Disease, 2(3), 207-221.

Geronimus, A.T. (2000). To mitigate, resist, or undo: Addressing structural influences on the health of urban populations. American Journal of Public Health, 90, 867-872.

Geronimus, A.T. (2013) Jedi Public Health: Leveraging Contingencies of Social Identity to Grasp and Eliminate Racial Health Inequality. In L Gomez \& N Lopez (eds). In Mapping 'Race' and Inequality: A Critical Reader on Health Disparities Research, Piscataway, NJ:Rutgers University Press.

Geronimus, A.T., Bound, J., \& Colen, C. (2011). Excess Black Mortality in the United States and Selected Black and White High Poverty Areas, 1980-2000. American Journal of Public Health, 101, 720-729.

Geronimus, A.T., Bound, J., \& Ro, A. (2010) Validity of Migration Zipcode Variable in 2000 Census. (Technical Benefits Memo February 2008).

Geronimus, A.T., Bound, J., Keene, D., \& Hicken, M. (2007). Black-white differences in age trajectories of hypertension prevalence among adult women and men, 1999-2002. Ethnicity and Disease 17:40-48.

Geronimus, A.T., Bound, J., \& Waidmann, T. (1999). Poverty, time and place: Variation in excess mortality across selected U.S. populations, 1980-1990. Journal of Epidemiological Community Health, 53(6), 325-334.

Geronimus, A.T., Bound, J., Waidmann, T.A., Colen, C.G., \& Steffick, D. (2001). Inequality in life expectancy, functional status, and active life expectancy across selected black and white populations in the United States. Demography, 38(2), 227-251. 
Geronimus, A.T., Bound, J., Waidmann, T., Hillemeier, M., \& Burns, P. (1996). Excess mortality among blacks and whites in the United States. New England Journal of Medicine 335, 1552-1558.

Geronimus, A.T., Hicken, M., Keene, D., \& Bound, J. (2006). “Weathering” and Age -Patterns of Allostatic Load Scores among Blacks and Whites in the United States. American Journal of Public Health 96(5), 826-833.

Geronimus, A.T., \& Thompson, J.P. (2004). To denigrate, ignore, or disrupt: The health impact of policy-induced breakdown of urban African American communities of support. $\mathrm{Du}$ Bois Review, 1(2), 247-279.

Gluckman PD, Hanson MA, Cooper C, Thornburg KL. Effect of in utero and early-life conditions on adult health and disease. N Engl J Med. 2008;359(1):61---73.

Halliday, T. J. and M. C. Kimmitt (2008). "Selective migration and health in the USA, 1984-93." Population Studies-a Journal of Demography 62(3): 321-334.

Hayward, M.D., \& Heron, M. (1999). Racial inequality in active life among adult Americans. Demography, 36(1), 77-91.

Hayward, M.D., Pienta, A.M., \& McLaughlin, D.K. (1997). Inequality in Men’s Mortality: The Socioeconomic status Gradient and Geographic Context. Journal of Health and Social Behavior 38, 313-330.

Hicks-Bartlett, S. (2000). Between a rock and a hard place: The labyrinth of working and parenting in a poor community. In Danziger S, Lin AC, (eds) Coping with poverty: The social contexts of neighborhood, work and family in the African-American community. Ann Arbor: University of Michigan Press, Chapter 2:27-51. 
Hunt, L.L., Hunt, M.O., et al. (2008). Who is Headed South? US Migration Trends in Black and White, 1970-2000. Social Forces 87(1), 95-119.

Hunt, M.O., Hunt, L.L., et al. (2012). "Call to Home?" Race, Region, and Migration to the US South, 1970-2000. Sociological Forum 27(1), 117-141.

Idler, E., \& Benyamini, Y. (1997). Self-rated health and mortality: A review of twenty-seven community studies. Journal of Health and Social Behavior 39, 21-37.

Jackson, M.I. and R.D. Mare. 2007."Cross-Sectional and Longitudinal Measurements of Neighborhood Experience and Their Effects on Children. Social Science Research 36 (2): 590-610.

James, S.A. (1994). John Henryism and the Health of African Americans. Culture, Medicine and Psychiatry 18: 163-182.

Jargowsky PA. (2003) Stunning Progress, Hidden Problems: The Dramatic Decline of Concentrated Poverty in the 1990s. Washington, DC: Brookings Institute.

Johnson, R.J., \& Wolinsky, F.D. (1993). The structure of health status among older adults: disease, disability, functional limitation, and perceived health. Journal of Health and Social Behavior 34(2), 105-121.

Keene, D., \& Geronimus, A.T. (2010). “Weathering” HOPE VI: The Importance of Evaluating the Population Health Impact of Public Housing Demolition and Displacement. Journal of Urban Health: Bulletin of the New York Academy of Medicine 88(3), 417-435.

Keene, D., Padilla, M., \& Geronimus, A.T.(2010). Leaving Chicago for Iowa's "Fields of Opportunity": Community Dispossession, Rootlessness, and the Quest for Somewhere to "Be OK." Human Organization 69(3), 275-284. 
Long, L. (1987). Migration and residential mobility in the United States. New York, Russell Sage Foundation.

Longino, C., Jackson, D., Zimmerman, R., \& Bardsher, J. (1991). The second move: Health and geographic mobility. Journal of Gerontology 46(4), S218-S224.

Longino, C.F.Jr., Bradley, D.E., Stoller, E.P., Haas, W.H III. (2008) Predictors of non-local moves among older adults: a prospective study. Journals of Gerontology Series B: Psychological Sciences and Social Sciences 63(1), S7-S14.

Manning, W., Newhouse, J., \& Ware, J, Jr. (1982). The status of health in demand estimation, or beyond excellent, good, fair and poor. In Fuchs V. (ed), Economic Aspects of Health (pp. 143-84). Chicago: University of Chicago Press.

Massey, D.S., \& Denton, N.A.. (1987). Trends in the residential segregation of Blacks, Hispanics, and Asians. American Sociological Review 52, 802-825.

Massey, D.S., \& Denton, N,A. (1993). American Apartheid: Segregation and the Making of the Underclass. Cambridge, MA: Harvard University Press.

Massey, D., Gross, A.B., \& Shibuya, K. (1994). Migration, segregation, and the geographic concentration of poverty. American Sociological Review 59,425-445.

Nordstrom, C.K., Diez-Roux, A.V., Jackson, S.A., \& Gardin, J.M. (2004). The association of personal and neighborhood socioeconomic indicators with subclinical cardiovascular disease in an elderly cohort. The Cardiovascular Health Study. Social Science \& Medicine 59(10), 2139-2147.

Norman, P., Boyle, P., \& Rees, P. (2005). Selective migration, health and deprivation: a longitudinal analysis, Social Science and Medicine 60, 2655-2771. 
Osypuk, T. L. and D. Acevedo-Garcia (2008). "Are Racial Disparities in Preterm Birth Larger in Hypersegregated Areas?" American Journal of Epidemiology 167(11): 1295-1304.

Palloni, A., \& Arias, E. (2004). Paradox lost: Explaining the Hispanic adult mortality advantage. Demography 41(3), 385-415.

Pearson, J.A. (2008) Can’t Buy Me Whiteness. DuBois Review 5(1), 27-48.

Shih, R., B. Ghosh-Dastidar, et al. (2011). "Neighborhood Socioeonomic Status and Cognitive Function in Women." American Journal of Public Health 101(9): 1721-1728

South, S.J., \& Crowder, K.D. (1997a). Escaping distressed neighborhoods: Individual, community, and metropolitan influences. American Journal of Sociology 102, 10401084.

South, S.J., \& Crowder, K.D.. (1997b). Residential mobility between cities and suburbs: Race, suburbanization, and back-to-the-city moves. Demography 34, 525-538.

South, S.J., Crowder, K., \& Chavez, E. (2005_. Exiting and entering poor neighborhoods: Latinos, Blacks, and Anglos compared. Social Forces 84(2), 873-900.

Speare, A., Avery, R., \& Lawton, L. (1991). Disability, residential mobility, and changes in living arrangements. Journal of Gerontology 46(3), S133-S142.

Tolnay, S. E. (2003). The African American "Great Migration" and Beyond. Annual Review of Sociology 29, 209-232.

Wallace, D., \& Wallace, R.. (1998) A Plague on Your Houses: How New York Was Burned Down and National Public Health Crumbled. London, UK: Verso.

Weisstein, E.W. (2012). "Bonferroni Correction." From MathWorld--A Wolfram Web Resource. http://mathworld.wolfram.com/BonferroniCorrection.html accessed 8/2012. 
Wilson, W.J. (1996). When work disappears: The world of the new urban poor. New York, NY: Vintage.

Wodtke, G.T., D.J. Harding and F. Elwert. 2011. "Neighborhood Effects in Temporal Perspective: The Impact of Long-Term Exposure to Concentrated Disadvantage on High School Graduation." American Sociological Review 76 (5): 713-736. 
Table 1. Economic characteristics and age-standardized death rates ${ }^{1}$, local black or white populations, 16-64 years, $2000^{2}$

\begin{tabular}{llllll}
\hline Area Type/Area & $\begin{array}{c}\text { Focal Area } \\
\text { Acronym }\end{array}$ & $\begin{array}{c}\text { Median } \\
\text { Income }\end{array}$ & $\begin{array}{c}\text { \% Families } \\
\text { < Poverty }\end{array}$ & Men & Women \\
\hline
\end{tabular}

U.S.

Black

44,173

25

1.84

1.90

High Poverty Urban

Harlem

East Detroit

Southside Chicago

Watts

High Poverty Rural

East North Carolina

Black Belt Alabama

Delta Louisiana

$\begin{array}{lllll}\text { har } & 35,896 & 35 & 2.25 & 2.36 \\ \text { edt } & 36,811 & 35 & 2.80 & 2.80 \\ \text { ssc } & 33,961 & 46 & 3.32 & 3.15 \\ \text { wts } & 33,993 & 38 & 2.89 & 2.52\end{array}$

$34,054 \quad 35$

$1.96 \quad 1.87$

bba

27,642

2.21

2.16

Nonpoor Urban

Bronx

dla

24,987

2.00

2.10

Queens

Northwest Detroit

Southwest Chicago

brx

55,205

0.96

1.07

qny

72,181

0.68

0.69

nwd

55,206

1.90

1.77

swd

50,268

2.13

2.04

Crenshaw/Baldwin Hills

cbh

55,759

1.79

1.65

U.S.

White

$\begin{array}{llll}70,526 & 08 & 1.00 & 1.00\end{array}$

\section{High Poverty Urban}

Cleveland

Detroit

$\begin{array}{lllll}\text { cld } & 43,017 & 18 & 1.75 & 1.43 \\ \text { det } & 43,952 & 23 & 2.72 & 2.36\end{array}$

\section{High Poverty Rural}

\begin{tabular}{llllll} 
Appalachian Kentucky & aky & 31,035 & 34 & 1.59 & 1.56 \\
West North Carolina & wnc & 48,137 & 14 & 1.05 & 1.02 \\
Northeast Alabama & nal & 46,861 & 14 & 1.43 & 1.24 \\
South Central Louisiana & cla & 45,238 & 18 & 1.32 & 1.34 \\
onpoor Urban & & & & & \\
Western Cleveland & wcl & 79,025 & 05 & 0.75 & 0.82 \\
Sterling Heights, MI & shd & 101,860 & 05 & 0.70 & 0.77 \\
\hline
\end{tabular}

${ }^{1}$ directly standardized with reference to the age distribution of the White population nationwide in 2000 according to gender.

${ }^{2}$ The 20 local population groups included Black or White residents of the following neighborhoods, counties, or health center districts. Black populations, Poor Urban Areas: Southside Chicago - Near Southside, Douglas, Oakland, Fuller Park, Grand Boulevard and Washington Park community areas located south of the Chicago Loop. Eastside Detroit - Central, University, Central Business District, Foch, Jefferson Mack, Airport, St. Jean, Chene, and Jeffries subcommunities of Detroit. $\underline{\text { Harlem }-}$ 
Central Harlem Health Center District. Watts - Watts and adjacent areas to the south and west. Poor Rural Areas: East North

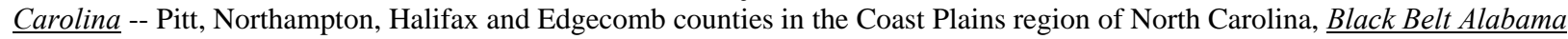
-- rural counties in and around the Black Belt region including Dallas, Fayette, Greene, Bibb, Sumter, Hale, Lamar, Marengo, Marion, Perry, and Pickens counties. Delta Louisiana -- Caldwell, East Carroll, Franklin, Jackson, Madison, Morehouse, Richland, Tensas, Union, West Carroll, Avoyelles, Catahoula, Concordia, Grant, La Salle, Vernon, and Winn parishes in the Mississippi River Delta region. Non-poor Urban Areas: Queens -- African-Americans living in eastern Queens in sections of the Jamaica East and Flushing Health Center Districts. Bronx -- African-Americans living in the north Bronx sections of the Pelham Bay Health Center District. Southwest Chicago -- African-Americans living in the Roseland, Pullman and West Pullman community areas. Northwest Detroit -- African-Americans living in the Palmer Park, Pembroke, Bagley, Redford, Rosedale Park, Evergreen and Greenfield neighborhoods.Crenshaw/Baldwin Hills -- African-Americans living in the Crenshaw, Ladera Heights, Leimert Park, Baldwin Hills and Windsor Hills communities. White populations, Poor Urban Areas: Central Cleveland --

Brooklyn-Centre, Clark-Fulton, Cudell, Detroit-Shoreway, Edgewater, Ohio City-Near West Side, Old Brooklyn, Stockyards and Tremont statistical planning areas on the near west side of Cleveland. Detroit -- Whites living in Delray, Clark Park, Chadsey, Condon, Springwells, Jeffries, State Fair, Burbank, Denby, Finney, Mt. Olivet, Grant, Davison, Pershing and Nolan subcommunities on the northeastern and southern periphery of Detroit Poor Rural Areas: Appalachian Kentucky -- Lee, Leslie, Owsley, Wolfe, Breathitt, Knott, Letcher, and Perry counties. West North Carolina -- Alleghany, Ashe, Avery, Mitchell, Watauga, Wilkes and Yancey counties. Northeast Alabama -- Whites living in DeKalb, Jackson and Marshall counties. South Central Louisiana -- Whites living in Acadia and Vermillion parishes Non-Poor Urban Areas: Cleveland -- Bay Village, Fairview Park, Lakewood, North Olmsted, Rocky River and Westlake communities. Sterling Heights -- Sterling Heights, a northern suburb of Detroit.

2

See Geronimus et al. (2011). 
Table 2. Fraction imputed or missing by total sample of valid movers, by local areas

\begin{tabular}{|c|c|c|c|c|c|c|c|}
\hline \multirow[t]{2}{*}{ Types } & \multirow[t]{2}{*}{$\begin{array}{l}\text { Imputed } \\
15 a^{*}\end{array}$} & \multicolumn{2}{|c|}{ Imputed Previous County } & \multicolumn{2}{|c|}{ Imputed Previous State } & \multicolumn{2}{|c|}{ Missing Zips } \\
\hline & & $\begin{array}{l}\text { Fraction of } \\
\text { Total }^{1}\end{array}$ & $\begin{array}{l}\text { Fraction } \\
\text { of } \\
\text { Movers }^{2}\end{array}$ & $\begin{array}{l}\text { Fraction of } \\
\text { Total }^{3}\end{array}$ & $\begin{array}{l}\text { Fraction } \\
\text { of } \\
\text { Movers }\end{array}$ & $\begin{array}{l}\text { Fraction of } \\
\text { Total }^{5}\end{array}$ & $\begin{array}{l}\text { Fraction } \\
\text { of } \\
\text { Movers }^{6}\end{array}$ \\
\hline Urban poor black & 0.08 & 0.02 & 0.08 & 0.02 & 0.06 & 0.10 & 0.32 \\
\hline Rural poor black & 0.07 & 0.01 & 0.04 & 0.01 & 0.04 & 0.06 & 0.20 \\
\hline Urban non-poor black & 0.09 & 0.02 & 0.06 & 0.01 & 0.05 & 0.08 & 0.31 \\
\hline Urban poor white & 0.05 & 0.01 & 0.03 & 0.01 & 0.03 & 0.08 & 0.20 \\
\hline Rural poor white & 0.04 & 0.01 & 0.03 & 0.01 & 0.03 & 0.06 & 0.18 \\
\hline Urban non-poor white & 0.03 & 0.01 & 0.03 & 0.01 & 0.03 & 0.06 & 0.17 \\
\hline
\end{tabular}

${ }^{*}$ Respondents were asked whether they had moved households within the past five years Numerator is people who did not respond to 15 a. Denominator is total population.

${ }^{1}$ Numerator is respondents answering that they moved dwelling units in 15a who did not respond to the question about county in 15b. Denominator is the total enumerated population.

${ }^{2}$ Numerator is respondents who answered that they moved dwelling units in 15a who did not respond to the question about county in $15 b$. Denominator is people who answered that they moved dwelling units in $15 \mathrm{a}$.

${ }^{3}$ Numerator is respondents answering that they moved dwelling units in 15 a who did not respond to the question about state in 15b. Denominator is the total enumerated population.

${ }^{4}$ Numerator is respondents who answered that they moved dwelling units in 15a who did not respond to the question about state in 15b. Denominator is people who answered that they moved dwelling units in 15a.

${ }^{5}$ Numerator is respondents answering that they moved dwelling units in 15a who did not respond to the question about ZIPcode in 15b. Denominator is the total enumerated population.

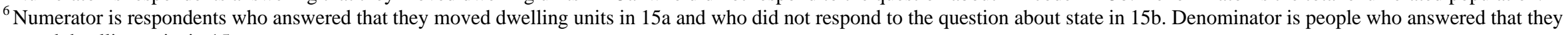
moved dwelling units in 15 
Table 3. 2000 local area population who moved

\begin{tabular}{|c|c|c|c|c|c|c|c|c|c|c|c|c|}
\hline \multirow[t]{2}{*}{ Black } & \multicolumn{4}{|c|}{ Urban High-Poverty } & \multicolumn{5}{|c|}{ Urban Non-Poor } & \multicolumn{3}{|c|}{ Rural High-Poverty } \\
\hline & $\begin{array}{l}\text { Harlem } \\
\text { NYC }\end{array}$ & $\begin{array}{l}\text { Eastside } \\
\text { Detroit }\end{array}$ & $\begin{array}{l}\text { Southside } \\
\text { Chicago }\end{array}$ & $\begin{array}{l}\text { Watts, Los } \\
\text { Angeles }\end{array}$ & Bronx & Queens & $\begin{array}{l}\mathrm{NW} \\
\text { Detroit }\end{array}$ & $\begin{array}{l}\text { Southwest } \\
\text { Chicago }\end{array}$ & $\begin{array}{l}\text { Crenshaw/ } \\
\text { BaldwinHills }\end{array}$ & $\begin{array}{l}\text { East North } \\
\text { Carolina }\end{array}$ & $\begin{array}{c}\text { Black Belt } \\
\text { Alabama Loı }\end{array}$ & $\begin{array}{l}\text { Delta } \\
\text { ouisiana }\end{array}$ \\
\hline \multicolumn{13}{|l|}{ Of all movers: } \\
\hline \% stayed in same local area & 47 & 47 & 42 & 47 & 33 & 32 & 37 & 40 & 38 & 76 & 83 & 80 \\
\hline \multicolumn{13}{|l|}{ Of movers from outside local area: } \\
\hline \% from same MSA & 81 & 87 & 84 & 92 & 93 & 92 & 89 & 90 & 88 & & & \\
\hline \% from other non-Southern MSA & 09 & 07 & 08 & 04 & 03 & 04 & 06 & 05 & 07 & 23 & 41 & 33 \\
\hline \% from Southern MSA & 08 & 05 & 06 & 03 & 03 & 03 & 03 & 02 & 04 & 42 & 38 & 35 \\
\hline$\%$ from rural non-South & NA & NA & NA & NA & NA & NA & NA & NA & NA & 02 & NA & 03 \\
\hline \% from rural South & NA & NA & NA & NA & NA & NA & NA & NA & NA & 33 & NA & 28 \\
\hline$\%$ from low poverty area & 07 & 05 & 07 & 08 & 07 & 20 & 11 & 08 & 13 & 10 & 10 & 09 \\
\hline$\%$ from moderate poverty area & 22 & 30 & 35 & 37 & 22 & 48 & 29 & 39 & 37 & 32 & 24 & 25 \\
\hline$\%$ from high poverty area & 38 & 49 & 24 & 32 & 34 & 20 & 39 & 29 & 27 & 37 & 41 & 27 \\
\hline$\%$ from very high poverty area & 33 & 15 & 32 & 22 & 37 & 12 & 21 & 24 & 23 & 21 & 25 & 38 \\
\hline
\end{tabular}

Notes: When cell size is too small for the Census to permit disclosure, the cell is labeled 'NA.' Low poverty: $<10 \%$ of adults in poverty; moderate poverty: 10 -20\% of adults in poverty; high poverty: 20-30\%; very high poverty: over $30 \%$. 
Table 3 cont'd. 2000 local area population who moved

\begin{tabular}{|c|c|c|c|c|c|c|c|c|}
\hline \multirow[t]{2}{*}{ White } & \multicolumn{4}{|c|}{ Urban High-Poverty Urban Non-poor } & \multicolumn{4}{|c|}{ Rural High Poverty } \\
\hline & Cleveland & Detroit & $\begin{array}{l}\text { West } \\
\text { Cleveland }\end{array}$ & $\begin{array}{l}\text { Sterling } \\
\text { Heights }\end{array}$ & $\begin{array}{l}\text { _l_ppalachian } \\
\text { Kentucky }\end{array}$ & $\begin{array}{l}\text { West } \\
\text { NC }\end{array}$ & $\begin{array}{l}\text { Northeast } \\
\text { Alabama }\end{array}$ & $\begin{array}{l}\text { SouthCentral } \\
\text { Louisiana }\end{array}$ \\
\hline \multicolumn{9}{|l|}{ Of all movers: } \\
\hline \% stayed in same local area & 49 & 51 & 47 & 27 & 83 & 64 & 75 & 71 \\
\hline \multicolumn{9}{|l|}{ Of movers from outside local area: } \\
\hline$\%$ from same MSA & 74 & 75 & 62 & 86 & & & & \\
\hline \% from other non-Southern MSA & 17 & 13 & 28 & 09 & 27 & 13 & 12 & 04 \\
\hline$\%$ from Southern MSA & 04 & 05 & 05 & NA & 22 & 62 & 63 & 59 \\
\hline$\%$ from rural non-South & 03 & NA & 04 & 02 & 09 & 06 & 03 & 02 \\
\hline$\%$ from rural South & 02 & NA & 01 & NA & 41 & 19 & 22 & 35 \\
\hline$\%$ from low poverty area & 81 & 70 & 76 & 87 & 40 & 77 & 60 & 38 \\
\hline$\%$ from moderate poverty area & 11 & 17 & 12 & 08 & 30 & 19 & 35 & 56 \\
\hline \% from high poverty area & 06 & 07 & 09 & 03 & 19 & 03 & 03 & NA \\
\hline$\%$ from very high poverty area & $02+$ & 05 & 03 & 02 & 11 & 01 & 02 & NA \\
\hline
\end{tabular}

Notes: When cell size is too small for the Census to permit disclosure, the cell is labeled 'NA.' Low poverty: $<10 \%$ of adults in poverty; moderate poverty: $10-20 \%$ of adults in poverty; high poverty: 20-30\%; very high poverty: over $30 \%$. 
Table 4. 1995 local area population who moved

\begin{tabular}{|c|c|c|c|c|c|c|c|c|c|c|c|c|}
\hline \multirow[t]{2}{*}{ Black } & \multicolumn{4}{|c|}{ Urban High-Poverty } & \multicolumn{5}{|c|}{ Urban Non-Poor } & \multicolumn{3}{|c|}{ Rural High-Poverty } \\
\hline & $\begin{array}{l}\text { Harlem } \\
\text { NYC } \\
\end{array}$ & $\begin{array}{l}\text { Eastside } \\
\text { Detroit }\end{array}$ & $\begin{array}{l}\text { Southside } \\
\text { Chicago }\end{array}$ & $\begin{array}{l}\text { Watts, Los } \\
\text { Angeles }\end{array}$ & Bronx & Queens & $\begin{array}{l}\mathrm{NW} \\
\text { Detroit }\end{array}$ & $\begin{array}{l}\text { Southwest } \\
\text { Chicago }\end{array}$ & $\begin{array}{l}\text { Crenshaw/ } \\
\text { BaldwinHills }\end{array}$ & $\begin{array}{l}\text { East North } \\
\text { Carolina }\end{array}$ & $\begin{array}{l}\text { Black } \\
\text { Alabama }\end{array}$ & $\begin{array}{l}\text { elt Delta } \\
\text { Louisiana }\end{array}$ \\
\hline \multicolumn{13}{|l|}{ Of all movers: } \\
\hline \% stayed in same local area & 38 & 37 & 40 & 33 & 29 & 24 & 30 & 25 & 37 & 74 & 73 & 68 \\
\hline \multicolumn{13}{|l|}{ Of movers from outside local area: } \\
\hline$\%$ went to same MSA & 65 & 88 & 79 & 86 & 65 & 62 & 81 & 77 & 81 & & & \\
\hline \% went to other non-Southern MSA & 14 & 05 & 11 & 08 & 12 & 11 & 08 & 12 & 11 & NA & 16 & NA \\
\hline \% went to Southern MSA & 16 & 04 & 08 & 05 & 19 & 22 & 09 & 09 & 07 & 70 & 73 & 69 \\
\hline$\%$ went to rural non-South & NA & NA & 01 & NA & 02 & 02 & 01 & 01 & NA & NA & NA & NA \\
\hline$\%$ went to rural South & NA & NA & 01 & NA & 02 & 03 & 02 & 01 & NA & 18 & NA & 14 \\
\hline \% went to low poverty area & 19 & 10 & 17 & 10 & 31 & 41 & 32 & 28 & 18 & 19 & 12 & 21 \\
\hline$\%$ went to moderate poverty area & 26 & 39 & 39 & 37 & 35 & 38 & 23 & 34 & 40 & 43 & 33 & 27 \\
\hline$\%$ went to high poverty area & 27 & 41 & 21 & 38 & 18 & 13 & 34 & 24 & 26 & 32 & 32 & 28 \\
\hline$\%$ went to very high poverty area & 27 & 10 & 23 & 15 & 16 & 09 & 11 & 13 & 17 & 06 & 23 & 25 \\
\hline
\end{tabular}

Notes: Notes: When cell size is too small for the Census to permit disclosure, the cell is labeled 'NA.' Low poverty: <10\% of adults in poverty; moderate poverty: 10-20\% of adults in poverty; high poverty: 20-30\%; very high poverty: over 30\%. South includes the following states: Virginia, North Carolina, South Carolina, Georgia, Florida, Alabama, Mississippi,

Louisiana, Texas, Arkansas, Oklahoma, and Tennessee 
Table 4 cont'd. 1995 local area population who moved

\begin{tabular}{lllllllll}
\hline White & & & & & & \\
\end{tabular}

Notes: When cell size is too small for the Census to permit disclosure, the cell is labeled 'NA.' Low poverty: <10\% of adults in poverty; moderate poverty: $10-20 \%$ of adults in poverty; high poverty: 20-30\%; very high poverty: over 30\%. South includes the following states: Virginia, North Carolina, South Carolina, Georgia, Florida, Alabama, Mississippi, Louisiana,

Texas, Arkansas, Oklahoma, and Tennessee. 
Table 5. Age-standardized disability prevalence by residential mobility status, selected local areas, 2000

MEN

Area Type/Area

Black

High Poverty Urban

Harlem
East Detroit
Southside Chicag
Watts

High Poverty Rural

East North Carolina

Black Belt Alabama

Delta Louisiana

Stayers

Movers

Out

$24^{*}$
$26^{* * *}$
27
28

30

32

28

30

34

27

31
26
$24 \dagger$

26
Non-poor Urban

Bronx

Queens

Northwest Detroit

Southwest Chicago

Crenshaw/Baldwin Hills

26

18

23*

21

26

$19 * * *$

22

Movers
In

Stayers

WOMEN

$\begin{array}{ll}\text { Movers } & \text { Movers } \\ \text { Out } & \text { In }\end{array}$

Out

In

27

26

32

30

29

29

32

$19 * * *$

23

33

31

24*

32

$28 \dagger$

24

33

35

22

22

26

21

17

23

22

19

21

19

26

$20 * * * \quad 29 *$

25

23

22

24

21

22

25

24

White

\section{High Poverty Urban}

Cleveland

Detroit

\section{High Poverty Rural}

Appalachian Kentucky 38

West North Carolina 22

Northeast Alabama 22

South Central Louisiana $\quad 25$

Non-poor Urban

Western Cleveland

Sterling Heights, MI
25

30
11

13

$23 \quad 20 *$

$21 * * * \quad 21 *$

34
$16^{*}$
23
25

32

$17^{* * *}$

20

21

10

$10 *$
12

12
23

23

24

27

$18^{* * *}$

30

$28 \quad 35$

15* $16^{*}$

$20 \quad 20$

17

17

19

10

10

12

12

13 
Table 6. Percent high school graduates (age-standardized) by residential mobility status, selected local areas, 2000

MEN

Area Type/Area

Black

High Poverty Urban

Harlem
East Detroit
Southside Chicago
Watts

High Poverty Rural

East North Carolina

Black Belt Alabama

Delta Louisiana

Non-poor Urban

Bronx

Queens

Northwest Detroit

Southwest Chicago

Crenshaw/Baldwin Hills

Stayers

Movers

Out

64

60

70

65

61

61

54

77

79

75

72

77
$72 *$

$70 * * *$

72

$73 * * *$

$72 * * *$

$73 *$

$74 * * *$

83

83

78

73

81
White

\section{High Poverty Urban}

Cleveland

Detroit

\section{High Poverty Rural}

Appalachian Kentucky

West North Carolina

Northeast Alabama

South Central Louisiana

Non-poor Urban

Western Cleveland

Sterling Heights, MI
67

63

56

71

68

67

88

87
Movers
In

$$
74 *
$$

$69 * * *$

80 ***

68

$$
64
$$

68

$69 * * *$
81

79

78

73

81

$81^{* * *}$

$81 * * *$

71

68

83

86

82

79

82
WOMEN

$\begin{array}{ll}\text { Movers } & \text { Movers } \\ \text { Out } & \text { In }\end{array}$

$75 *$

74

$73^{* * *}$

$74 * * *$

75

$85 * * *$

73*

71

$\begin{array}{ll}76^{*} & 76^{*} \\ 68 & 75^{*} \\ 77^{* * *} & 71^{*}\end{array}$

86

80

$87 \quad 87$

85* $\quad 79$

82* $\quad 80$

81

80 
Table 7. Log Odds [standard errors] of moving between 1995 and 2000 by type of area, disability status, and education

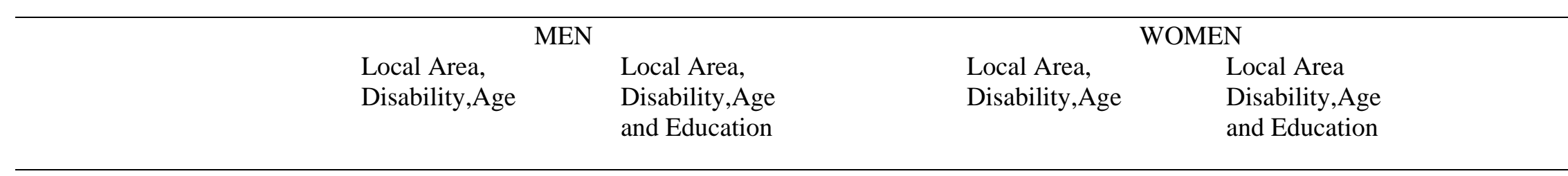

\section{MOVING OUT}

\section{Black}

\section{High Poverty Urban}

Disabled $\quad-0.28[0.07]^{* * *}$
HS Grad
College Grad

\section{High Poverty Rural}

Disabled
HS Grad
College Grad

$-0.22[0.06]^{* * *}$

Disabled

HS Grad

College Grad

\section{White}

High Poverty Urban

Disabled $\quad-0.36[0.08]^{* * *}$

$$
\begin{gathered}
-0.22[0.07]^{* * *} \\
0.41[0.07]^{* * *} \\
0.76[0.10]^{* * *}
\end{gathered}
$$

$-0.21[0.05]^{* * *}$

$$
-0.15[0.10]
$$$$
1.09[0.11]^{* * *}
$$$$
1.97[0.18]^{* * *}
$$

$-0.27[0.09]^{* * *}$

$$
\begin{aligned}
& -0.19[0.06]^{* * *} \\
& 0.13[0.08] \dagger \\
& 0.16[0.11]
\end{aligned}
$$

$-0.15[0.05]^{* * *}$

$$
\begin{aligned}
& -0.12[0.05]^{*} \\
& 0.33[0.07]^{* * *} \\
& 0.39[0.08]^{* * *}
\end{aligned}
$$

$-0.15[0.05]^{* * *}$
$0.23[0.10]^{* * *}$
$0.58[0.08]^{* * *}$

$-0.14[0.09]$

$0.73[0.09]^{* * *}$

$1.63[0.13]^{* * *}$
$-0.22[0.08]^{* * *}$
$0.51[0.08]^{* * *}$ 
College Grad

\section{High Poverty Rural}

Disabled

HS Grad

College Grad

Non-poor Urban

Disabled

HS Grad

College Grad
$-0.21[0.09]^{*}$

$0.91[0.11]^{* * *}$

$-0.25[0.07]^{* * *}$

$0.04[0.07]$

$0.73[0.08]^{* * *}$

$2.11[0.09]^{* * *}$

$-0.13[0.09]$
$0.68[0.11]^{* * *}$
$0.87[0.12]^{* * *}$

$-0.13[0.09]$

$0.87[0.12]^{* * *}$
$0.96[0.11]^{* * *}$

$0.01[0.07]$

$0.56[0.07]^{* * *}$

$1.61[0.08]^{* * *}$

$-0.08[0.09]$

$0.81[0.11]^{* * *}$

$0.99[0.12]^{* * *}$

\section{MOVING IN}

Black

\section{High Poverty Urban}

Disabled

HS Grad

College Grad

High Poverty Rural

$\begin{array}{ll}\text { Disabled } & -0.40[0.11]^{* * *} \\ \text { HS Grad } & \\ \text { College Grad } & \\ \text { on-poor Urban } & \\ \text { Disabled } & -0.19[0.07]^{* * *} \\ \text { HS Grad } & \\ \text { College Grad } & \end{array}$

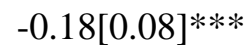

$-0.32[0.11]^{* * *}$

$0.48[0.11]^{* * *}$

$1.16[0.19]^{* * *}$

$-0.18[0.07]^{*}$

$0.13[0.08] \dagger$

$0.16[0.11]$
$-0.24[0.06]^{* * *}$

$-0.14[0.06]^{*}$

$0.32[0.07]^{* * *}$

$1.01[0.09]^{* * *}$

$-0.13[0.10]$

$0.50[0.11]^{* * *}$

$0.99[0.15]^{* * *}$

0.02[0.06]

$-0.02[0.07]$

$0.02[0.09]$ 


\section{White}

\section{High Poverty Urban}

Disabled
HS Grad
College Grad

$-0.23[0.11]^{*}$
$0.94[0.12]^{* * *}$
$2.01[0.14]^{* * *}$

$-0.34[0.10]^{* * *}$

$0.20[0.11] \dagger$

$2.01[0.14]^{* * *}$

$0.87[0.12]^{* * *}$

$2.03[0.14]^{* * *}$

High Poverty Rural

\begin{tabular}{|c|c|c|c|c|}
\hline Disabled & $-0.29[0.06]^{* * *}$ & $-0.08[0.06]$ & $-0.22[0.06]^{* * *}$ & $0.06[0.06]$ \\
\hline HS Grad & & $0.65[0.66]^{* * *}$ & & $0.51[0.07]^{* * *}$ \\
\hline College Grad & & $1.60[0.08]^{* * *}$ & & $1.12[0.08]^{* * *}$ \\
\hline \multicolumn{5}{|l|}{ on-poor Urban } \\
\hline Disabled & $-0.11[0.09]$ & $-0.05[0.10]$ & $-.25[0.08]^{* * *}$ & $0.11[0.09]$ \\
\hline HS Grad & & $0.31[0.12]^{* * *}$ & & $0.77[0.13]^{* * *}$ \\
\hline College Grad & & $0.47[0.13]^{* * *}$ & & $1.09[0.13]^{* * *}$ \\
\hline
\end{tabular}

Note: Note: All models include age-dummies and area-specific effects. So, for example, the models for poor urban blacks include controls for whether the individual lived in Harlem, Detroit, Chicago or Los Angeles. The HS Grad category includes college graduates. Numbers in brackets represent standard errors.

$\dagger$ significant $\mathrm{p}<.10$; * significant $\mathrm{p}<.05$; ** significant $\mathrm{p}<.01$; *** significant $\mathrm{p}<.001 \%$ 
Table 8. Estimates of age-standardized percent disability prevalence based on 1995 and 2000 local area populations

\section{BLACK}

\begin{tabular}{cccr}
\multicolumn{4}{c}{ Disability Prevalence } \\
1995 & 2000 & 1995 & 2000
\end{tabular}

\section{High poverty Urban}

Harlem
Eastside Detroit
Southside Chicago
Watts

High poverty Rural

East North Carolina

Black Belt Alabama

Delta Louisiana

\section{Non-poor Urban}

Bronx

Queens

Northwest Detroit

Southwest Chicago

Crenshaw/Baldwin Hills

WHITE

\section{High poverty Urban}

Cleveland

Detroit

\section{High poverty Rural}

Appalachian Kentucky

West North Carolina

Northeast Alabama

South Central Louisiana

\section{Non-poor Urban}

29.2

30.0

33.0

26.3

27.1

30.4

29.0

31.4

28.4

24.1

20.6

25.5

24.4

23.8

23.9

26.9

37.9

21.4

21.9

24.4

10.8

11.9
23.3

$28.7 \dagger$

38.1

21.3

21.7

24.2

10.8

12.4

10.8
11.9

31.3

31.6

31.9

31.5

27.1

26.1

30.0

31.3

27.3

30.9

25.8

$25.6 \quad 25.8$

20.4

21.4

19.1

18.5

24.5

$25.7 * *$

22.5

22.9

22.6

22.4
Western Cleveland

Sterling Heights, Michigan

Note: and 2000 is statistically significant at the $\mathrm{p}<.0 .10$ level, ** indicates the difference between 1995 and 2000 is statistically significant at the $\mathrm{p}<0.01$ level. while *** indicates the difference between 1995 and 2000 is statistically significant at the $\mathrm{p}<0.001$ level. $\mathrm{P}$ values are calculated using the method proposed by Bonferroni (Weisstein 2012). 
Figure 1. Percent of the 2000 local area populations who moved between 1995 and 2000

Blacks

Moved Dwelling Units

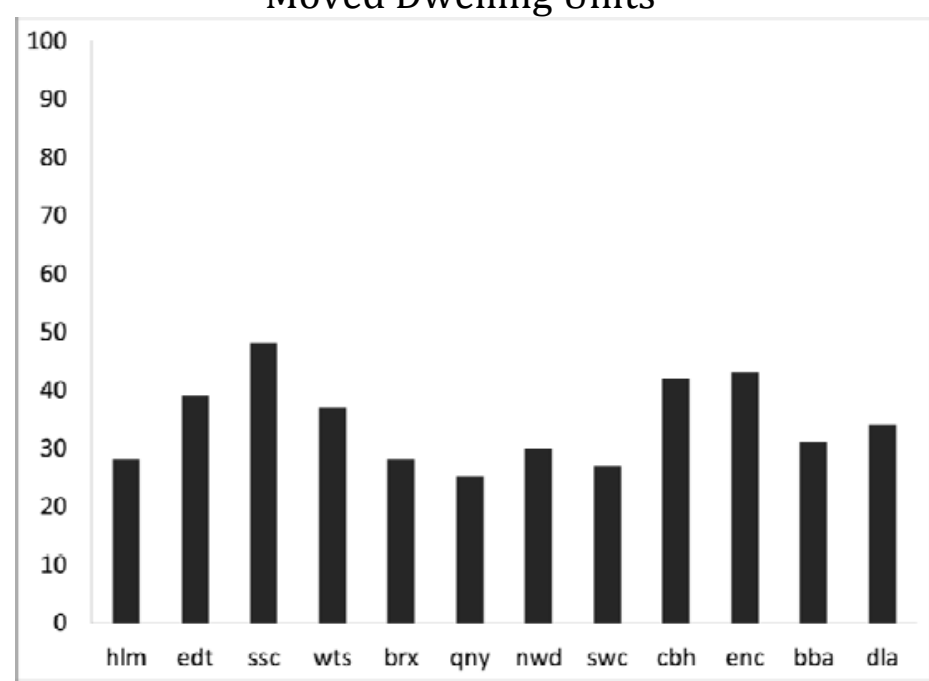

Whites

Moved Dwelling Units

Movers in who stayed in the same zipcode, local area, county or state
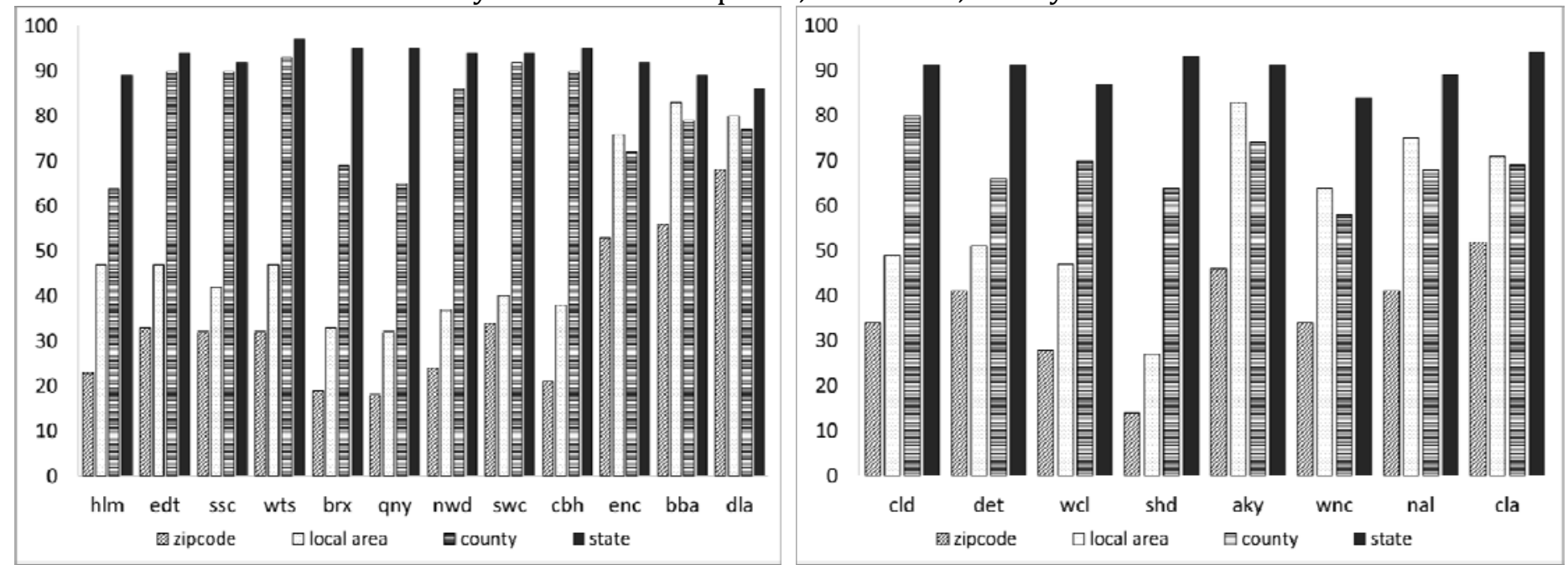

Movers out who stayed in the same zipcode, local area, county or state
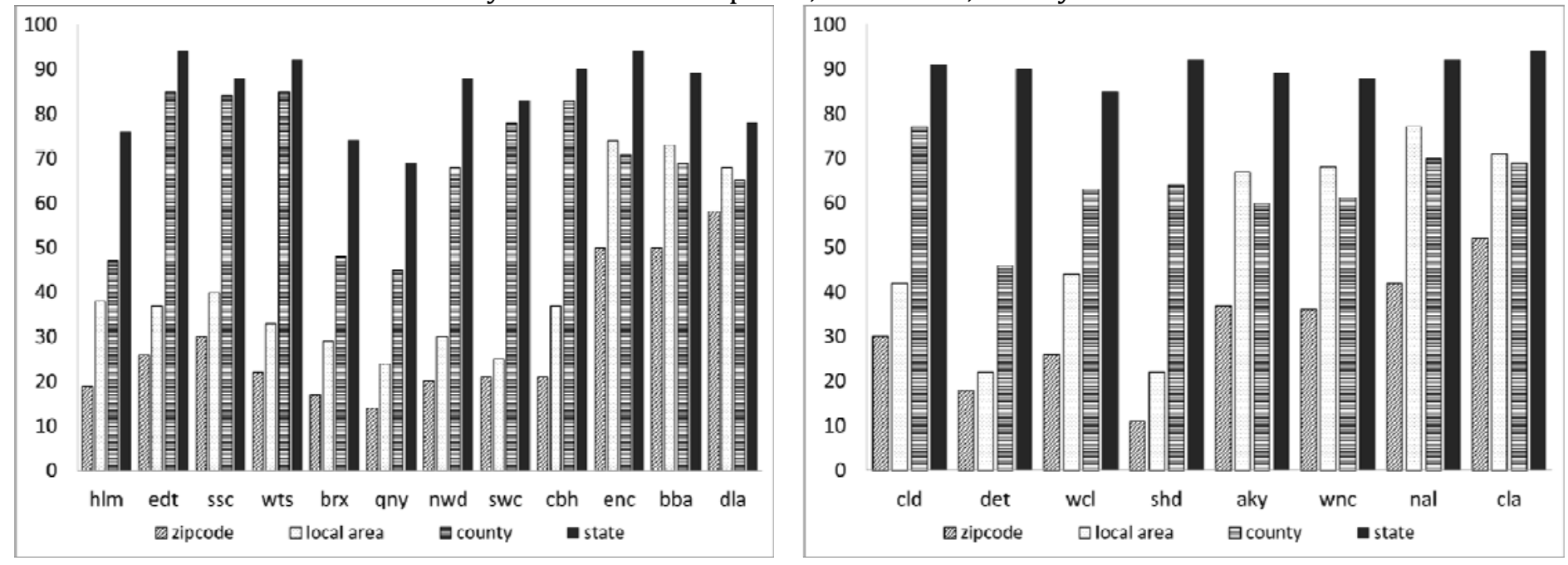